\title{
Recent sea-level changes in the southern Bay of Biscay: transfer function reconstructions from salt-marshes compared with instrumental data
}

\author{
EDUARDO LEORRI ${ }^{1,2}$ and ALEJANDRO CEARRETA ${ }^{3}$ \\ ${ }^{1}$ Departamento de Geologia, Facultade de Ciências da Universidade de Lisboa. Edificio C6, $3^{\circ}$ piso, Campo Grande, 1749- \\ 016, Lisboa, Portugal. E-mail: eduleorri@yahoo.es \\ ${ }^{2}$ Sociedad de Ciencias Aranzadi, Zorroagagaina kalea 11, 20014 Donostia-San Sebastian, Spain. \\ ${ }^{3}$ Departamento de Estratigrafía y Paleontología, Facultad de Ciencia y Tecnología, Universidad del País Vasco/EHU, \\ Apartado 644, 48080 Bilbao, Spain.
}

\begin{abstract}
SUMMARY: In order to assess the accuracy and regional significance of salt-marsh reconstructions of former sea level based on foraminiferal transfer functions, we compared the calibration of the foraminiferal assemblages of two salt-marsh cores from two estuaries using the regional transfer function constructed for the southern Bay of Biscay. The foraminiferabased reconstructions were placed into a temporal framework using ${ }^{137} \mathrm{Cs}$, heavy metal concentrations, and ${ }^{210} \mathrm{~Pb}-\mathrm{derived}$ sediment accumulation rates. The resulting relative sea-level (RSL) curves were compared with the nearest tide-gauge data (Santander). The two RSL trends from core sediments show excellent agreement and are in very good agreement with instrumental data, providing a regional relative sea-level rise of $1.9 \mathrm{~mm} \mathrm{yr}^{-1}$ for the 20 th century.
\end{abstract}

Keywords: marsh foraminifera, transfer function, ${ }^{137} \mathrm{Cs}$, heavy metal concentrations, ${ }^{210} \mathrm{~Pb}$ dating, sea level, Bay of Biscay.

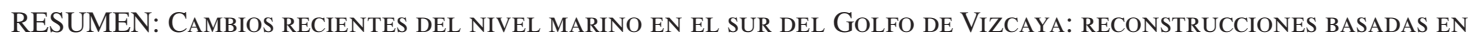
FUNCIONES DE TRANSFERENCIA APLICADAS EN MARISMAS EN COMPARACIÓN CON DATOS INSTRUMENTALES. - Con el fin de evaluar la precisión y el carácter regional de las reconstrucciones del nivel marino basadas en funciones de transferencia usando foraminíferos de marisma, hemos comparado la calibración de las asociaciones de foraminíferos de dos sondeos perforados en sendos estuarios, usando una función de transferencia de validez regional construida para el sur del Golfo de Vizcaya. Estas reconstrucciones basadas en las asociaciones de foraminíferos han sido situadas en un marco temporal utilizando ${ }^{137} \mathrm{Cs}$, concentraciones de metales pesados y los cocientes de acumulación sedimentaria basados en ${ }^{210} \mathrm{~Pb}$. La curva del nivel marino resultante ha sido comparada con el mareógrafo más próximo al área de estudio (Santander). Las dos curvas obtenidas a partir de los sondeos presentan una excelente correlación entre sí y muy buena correlación con los datos procedentes del mareógrafo, proporcionando un ascenso relativo del nivel marino de $1.9 \mathrm{~mm}$ año ${ }^{-1}$ para el siglo XX, siendo este ascenso de carácter regional.

Palabras clave: foraminíferos de marisma, función de transferencia, ${ }^{137} \mathrm{Cs}$, concentraciones de metales pesados, dataciones de ${ }^{210} \mathrm{~Pb}$, nivel marino, Golfo de Vizcaya.

\section{INTRODUCTION}

Historical instrumental data provide a global sealevel rise (GSLR) rate of $1.8 \mathrm{~mm} \mathrm{yr}^{-1}$ (IPCC, 2007). However, the spatial and temporal coverage of tide gauges is heterogeneous and limited, and therefore does not capture regional variability (Douglas, 2001) and cannot provide a meaningful estimate of the average GSLR for the past century (Cabanes et al., 2001). Since 1993 satellite altimetry data have been 
available and provide new estimates of $\sim 3 \mathrm{~mm} \mathrm{yr}^{-1}$ (Cabanes et al., 2001; Cazenave and Nerem, 2004; Leuliette et al., 2004). These differences could be related to the acceleration in sea-level rise found by Church and White (2006) for the period 1870-2000, or represent decadal variability (Nerem et al., 2006). Furthermore, an important question to address is to identify when the modern rate of sea-level rise began. Therefore, estimating sea-level rise from sedimentary sequences of salt marshes has received increasing attention, since this research offers great potential to supplement the temporal and spatial global database of instrumental (tide-gauge) observations of sealevel change. These sequences provide a benchmark against which one must measure the additional sealevel rise that has occurred over the last 100-150 years (Church and White, 2006; Holgate, 2007). In fact, recent geologically-based research from the North Atlantic has provided the first indication that modern rates of relative sea-level (RSL) rise (last 100 years) in this region may be more rapid than the long-term rate of rise (over the last $800-1000$ years), and that the timing of this acceleration may be indicative of a link with human-induced climate change (Gehrels et al., 2002, 2004, 2005; Donnelly et al., 2004). Advances in high-resolution sea-level reconstruction have been made in the last few years through the development of foraminifera-based transfer functions (Gehrels et al., 2002; Edwards et al. 2004; Gehrels, 2004; Hayward et al., 2004; Boomer and Horton, 2006; Horton and Edwards, 2006). Fossil foraminifera have been used as "proxies" for elevation by quantifying the relationship between faunal data (relative abundance of individual species) and environmental data (elevation) in the modern salt-marsh environment. These modern relationships are then applied to cores to reconstruct past tide levels from fossil assemblages within sedimentary sequences in order to reconstruct palaeomarsh surface elevation. In the southern Bay of Biscay, Leorri et al. (2008a) developed a foraminifera-based transfer function from four Basque marshes. The relationship between observed and foraminifera-predicted elevation was strong, allowing precise reconstructions of former sea levels (error ranged from 0.11 to $0.19 \mathrm{~m}$ ). The transfer function was used to calibrate the foraminiferal assemblages collected from a 50-cm salt-marsh core. The resulting relative sea-level curve was in very good agreement with regional tide-gauge data, suggesting a rate of RSL rise of approximately $2 \mathrm{~mm}$ $\mathrm{yr}^{-1}$ for the 20th century.
However, we argue that a single core analysis could reflect local rather than regional forcing factors. Consequently, we hypothesise that regional signals should be recorded in different marsh areas and be coincident with tide-gauge data. Therefore, we apply here the transfer function developed previously by Leorri et al. (2008a) to a $50 \mathrm{~cm}$-long core recovered from the Muskiz marsh (Fig. 1). We describe the application of this transfer function and also assess its performance in reconstructing palaeomarsh-surface elevation. We compare the derived relative sea-level curve with both the previously reconstructed sealevel curve from the nearby Ostrada marsh (Leorri et al., 2008a) and regional Santander tide-gauge data in order to provide a quantitative assessment of the potential of intertidal foraminifera for RSL studies in the Bay of Biscay.

\section{MATERIALS AND METHODS}

A $50 \mathrm{~cm}$ sediment core was collected from the Muskiz marsh in November 2003. Compaction of the sediment during sampling was negligible due to the thin marsh lithosome, the dominance of minerogenic sediments, and the proximity to the basal contact with Mesozoic-Cenozoic rocks that provide little opportunity for additional accommodation space due to autocompaction (loss of porosity due to the load of overlying sediments) (Leorri et al., 2008a). The Muskiz marsh (Fig. 1) is located in the middle reaches of the Barbadun estuary and characterised by halophytic plants: Sarcocornia perennis, Sarcocornia fruticosa and Salicornia ramossissima together with Atriplex portulacoides and Puccinellia maritima, among others (Anonymous, 1986). The Barbadun estuary forms the tidal part of the Barbadun river. It has a total surface area of 204 ha, a length of $4.4 \mathrm{~km}$ and an average width of 5-10 m (Anonymous, 1999). Aerial and historical photography indicate that the selected area does not have a history of reclamation. Furthermore, sedimentological investigations did not reveal any agricultural layers as identified in many other salt marshes of northern Spain (e.g. Cearreta $e t$ $a l ., 2002)$. Two PVC tubes ( $12.5 \mathrm{~cm}$ diameter) were inserted into the sediment in order to obtain sufficient material to determine grain size, benthic foraminifera, sediment geochemistry, organic matter, and ${ }^{137} \mathrm{Cs}$ and ${ }^{210} \mathrm{~Pb}$ geochronologies. The core was described, photographed and X-radiographed before being sliced into samples of one centimetre thickness. 


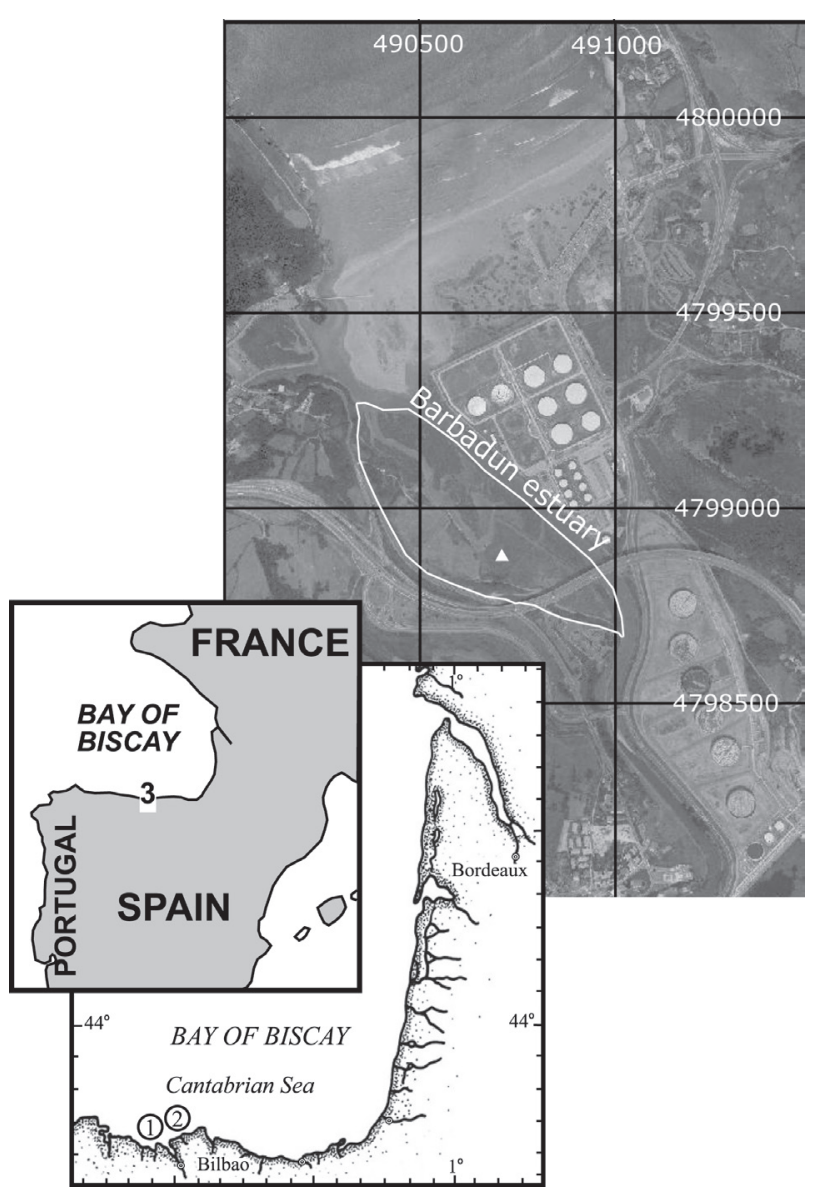

FIG. 1. - Location of the Muskiz marsh (highlighted by the white border) in the Barbadun estuary and localities referred to in the text. Key: 1-Barbadun estuary; 2-Ostrada marsh; 3-Santander. White triangle in the Muskiz marsh indicates location of core.

We measured topographic elevation (Leica station; elevation error: $\pm 0.005 \mathrm{~m}$ ) for the core and this information is presented relative to the local ordnance datum (lowest tide at the Bilbao Harbour on 27th September 1878).

Since the transfer function has been developed from four different marsh areas, the inundation frequency at each study area must be calculated and elevations are standardised relative to the tidal range. Hence, the elevations are expressed as a standardised water level index (SWLI; Hamilton and Shennan, 2005):

$$
S W L I_{n}=\frac{100\left(h_{n}-h_{M T L}\right)}{h_{M H H W}-h_{M T L}}+100
$$

where $S W L I_{n}$ is the standardised water level index for sample $n, h_{n}$ the elevation of sample $n, h_{M T L}$ the mean tide level elevation, and $h_{M H H W}$ the mean higher high water elevation, all of them expressed in metres above local ordnance datum. This produces a stand- ardised water level index (SWLI) for each modern sample, with 100 representing the mean tide level and 200 the mean higher high water. SWLI for each buried sample is then converted back to an elevation above local ordnance datum at the field site by reversing the calculations (Hamilton and Shennan, 2005).

\section{Microfaunal study}

We analysed the samples of the Muskiz core for foraminiferal content at $1 \mathrm{~cm}$ intervals. Samples were sieved through a $1 \mathrm{~mm}$ sieve (to remove large organic fragments) and a 63 micron sieve and washed to remove clay and silt material. Tests were picked until a representative number of more than 300 individuals was obtained, and then studied under a stereoscopic binocular microscope using reflected light. The total number of samples analysed in this core was 23 , and more than 7100 foraminifera were identified. Foraminiferal species identified in this core with relative abundances greater than $2 \%$ are presented in Table 1.

\section{Radiometric analysis}

Core sub-samples were dried, homogenised and then placed in sealed $9 \mathrm{ml}$ Petri dishes in order to obtain the radioactive equilibrium between ${ }^{226} \mathrm{Ra}$ and ${ }^{222} \mathrm{Rn}$ daughters over 60 days. The concentration of existing radioactive isotopes in each sample was determined by means of a semi-planar detector (EGSP 2200-25-r, EURO-YSIS Measures) coupled with a multi-channel analyser (8000 channels) at the University of Bordeaux (France).

The concentrations of the radioactive elements ${ }^{137} \mathrm{Cs},{ }^{226} \mathrm{Ra}$ and ${ }^{210} \mathrm{~Pb}$ were determined by the number of counts beneath the corresponding photopeaks, taking into account background noise and spectrum base line. The photopeaks considered here are: $661 \mathrm{KeV}$ from the ${ }^{137} \mathrm{Cs}, 46.5 \mathrm{KeV}$ from the ${ }^{210} \mathrm{~Pb}, 352$ and $611 \mathrm{KeV}$ from the ${ }^{214} \mathrm{~Pb}$ and ${ }^{214} \mathrm{Bi}$, daughter products of the ${ }^{222} \mathrm{Rn}$ in equilibrium with the ${ }^{226} \mathrm{Ra}$ (Lederer et al., 1967). Each sample was counted for a period of 24 hours. The detection efficiency of the measuring system was calculated using samples of known activity prepared with the same geometry as the samples to be measured. The uncertainties of the measured concentrations are due mainly to the statistical counting error, and depend on each value. 
TABle 1. - Relative abundances (>2\%) of main foraminiferal species in the Muskiz core samples. A.tep, Ammonia tepida; C.lob, Cibicides lobatulus; C.wil, Cribroelphidium williamsoni; G.rud, Gaudryina rudis; H.ger, Haynesina germanica; J.mac, Jadammina macrescens; M.sec, Massilina secans; Q.lat, Quinqueloculina lata; Q.sem, Quinqueloculina seminula; R.ano, Rosalina anomala; T.inf, Trochammina inflata; N, number of test picked.

\begin{tabular}{|c|c|c|c|c|c|c|c|c|c|c|c|c|c|c|c|}
\hline Sample & $\begin{array}{l}\text { Depth } \\
\text { (m) }\end{array}$ & $\begin{array}{l}\text { Elevation } \\
\quad(\mathrm{m})\end{array}$ & A.tep & C.lob & C.wil & G.rud & H.ger & J.mac & M.sec & Q.lat & Q.sem & R.ano & T.inf & $\mathrm{N}$ & $\mathrm{N} \mathrm{g}^{-1}$ \\
\hline M\#1 & 0.01 & 4.51 & 0.3 & 0.3 & 0.0 & 0.0 & 0.0 & 77.1 & 0.0 & 0.0 & 0.9 & 0.0 & 18.1 & 332 & 1443 \\
\hline M\#3 & 0.03 & 4.49 & 0.0 & 0.0 & 0.0 & 0.0 & 0.0 & 88.8 & 0.0 & 0.0 & 0.0 & 0.0 & 11.3 & 311 & 3809 \\
\hline $\mathrm{M \# 5}$ & 0.05 & 4.47 & 0.7 & 3.6 & 0.0 & 0.0 & 0.0 & 88.8 & 0.0 & 0.0 & 0.0 & 0.0 & 6.6 & 303 & 1700 \\
\hline $\mathrm{M \# 7}$ & 0.07 & 4.45 & 1.0 & 5.4 & 0.0 & 0.0 & 0.0 & 84.4 & 0.0 & 0.3 & 0.0 & 0.0 & 7.7 & 313 & 1842 \\
\hline M\#9 & 0.09 & 4.43 & 0.7 & 1.0 & 0.0 & 0.0 & 0.0 & 87.7 & 0.0 & 0.0 & 0.0 & 0.0 & 10.4 & 309 & 947 \\
\hline M\#11 & 0.11 & 4.41 & 0.0 & 1.3 & 0.0 & 0.0 & 0.0 & 79.5 & 0.0 & 0.0 & 0.0 & 0.0 & 18.9 & 302 & 114 \\
\hline M\#13 & 0.13 & 4.39 & 0.0 & 0.0 & 0.0 & 0.0 & 0.0 & 80.6 & 0.0 & 0.0 & 0.0 & 0.0 & 19.4 & 309 & 396 \\
\hline M\#15 & 0.15 & 4.37 & 0.0 & 5.6 & 0.0 & 0.0 & 0.0 & 69.9 & 0.0 & 0.3 & 0.0 & 0.3 & 23.2 & 302 & 144 \\
\hline M\#17 & 0.17 & 4.35 & 3.6 & 53.4 & 4.3 & 0.0 & 3.3 & 18.0 & 0.7 & 0.3 & 0.0 & 3.3 & 8.2 & 305 & 316 \\
\hline M\#19 & 0.19 & 4.33 & 3.6 & 68.1 & 3.2 & 0.0 & 1.0 & 7.7 & 0.3 & 1.9 & 0.3 & 5.2 & 0.0 & 310 & 524 \\
\hline M\#21 & 0.21 & 4.31 & 2.2 & 55.7 & 2.9 & 0.0 & 1.9 & 9.8 & 1.9 & 5.1 & 4.4 & 4.7 & 0.6 & 316 & 385 \\
\hline $\mathrm{M} \# 23$ & 0.23 & 4.29 & 2.6 & 62.3 & 1.3 & 1.0 & 3.0 & 0.0 & 3.6 & 5.9 & 5.9 & 5.3 & 0.0 & 305 & 359 \\
\hline $\mathrm{M} \# 25$ & 0.25 & 4.27 & 2.2 & 55.0 & 5.8 & 2.2 & 1.9 & 0.3 & 3.2 & 6.4 & 5.4 & 5.8 & 0.0 & 313 & 436 \\
\hline $\mathrm{M} \# 27$ & 0.27 & 4.25 & 3.9 & 56.7 & 5.2 & 2.0 & 2.6 & 0.0 & 3.9 & 4.9 & 4.9 & 4.6 & 0.0 & 305 & 166 \\
\hline M\#29 & 0.29 & 4.23 & 1.9 & 56.4 & 5.3 & 3.7 & 2.8 & 0.0 & 4.7 & 5.0 & 7.8 & 3.4 & 0.0 & 321 & 110 \\
\hline M\#31 & 0.31 & 4.21 & 1.6 & 56.2 & 5.7 & 1.3 & 3.2 & 0.0 & 3.8 & 5.4 & 6.9 & 4.4 & 0.0 & 319 & 182 \\
\hline M\#33 & 0.33 & 4.19 & 2.6 & 59.0 & 4.9 & 1.3 & 0.3 & 0.0 & 2.6 & 6.2 & 7.9 & 3.6 & 0.0 & 305 & 263 \\
\hline M\#35 & 0.35 & 4.17 & 1.3 & 57.6 & 2.7 & 1.3 & 0.3 & 0.0 & 4.6 & 6.0 & 7.6 & 3.3 & 0.0 & 302 & 198 \\
\hline M\#37 & 0.37 & 4.15 & 2.2 & 57.6 & 2.5 & 1.3 & 1.9 & 0.0 & 3.8 & 7.0 & 6.7 & 3.8 & 0.0 & 316 & 235 \\
\hline M\#39 & 0.39 & 4.13 & 2.6 & 56.6 & 2.6 & 1.0 & 3.3 & 0.0 & 3.0 & 10.5 & 6.6 & 2.3 & 0.0 & 304 & 262 \\
\hline M\#41 & 0.41 & 4.11 & 2.6 & 57.1 & 6.4 & 1.6 & 1.9 & 0.0 & 2.9 & 8.6 & 6.4 & 5.1 & 0.0 & 313 & 176 \\
\hline M\#43 & 0.43 & 4.09 & 1.3 & 52.9 & 7.5 & 1.6 & 1.6 & 0.0 & 2.9 & 5.5 & 6.2 & 3.3 & 0.0 & 308 & 286 \\
\hline M\#45 & 0.45 & 4.07 & 2.9 & 52.3 & 5.8 & 2.6 & 1.0 & 0.0 & 3.9 & 4.9 & 7.1 & 3.3 & 0.0 & 308 & 263 \\
\hline
\end{tabular}

\section{Geochemical analysis}

The sediments were sieved through a $1 \mathrm{~mm}$ sieve, oven-dried at $45^{\circ} \mathrm{C}$ and mechanically homogenised in an agate mill to avoid metal contamination. Metal concentrations were determined by inductively coupled plasma-optic emission spectrometry (ICPOES) after microwave digestion with aqua regia. Lowest detection limits were $0.1 \mathrm{mg} \mathrm{kg}^{-1}$ for Sc; 1 $\mathrm{mg} \mathrm{kg}^{-1}$ for $\mathrm{Mn}, \mathrm{Zn}, \mathrm{Cu}$ and $\mathrm{Ni} ; 2 \mathrm{mg} \mathrm{kg}^{-1}$ for $\mathrm{Pb}$ and $\mathrm{Cr} ; 3 \mathrm{mg} \mathrm{kg}^{-1}$ for As; and $0.01 \%$ for $\mathrm{Fe}$ and $\mathrm{Ca}$. Organic matter analysis was performed following the Walkey method (Hesse, 1971).

\section{Statistic analysis}

The performance of the transfer functions is assessed in terms of the root-mean square of the error of prediction (RMSEP) and the squared correlation $\left(r^{2}\right)$ of observed versus predicted values. The RMSEP indicates the systematic differences in prediction errors, whereas the $r^{2}$ measures the strength of the relationship of observed versus predicted values. These statistics are calculated as "apparent" measures in which the whole training set is used to generate the transfer function and assess the predictive ability, and the data were also jack-knifed (also known as 'leaveone-out' measures). Jack-knifing is a measure of the overall predictive abilities of the dataset. However, it does not provide sample-specific errors for the palaeomarsh elevation reconstructions of each core sample (Birks, 1995). Bootstrapping can be used to derive a standard error of prediction (SEpred; Birks et al., 1990; Line et al., 1994), which varies from sample to sample depending upon the composition of the core assemblage and the presence or absence of taxa with a particularly strong signal for the environmental variable of interest (Birks, 1995). SEpred was estimated using 1000 cycles. We will use here the Model 3 (WA-PLS; component 3, see Table 2) transfer function described by Leorri et al. (2008a). Model 3 uses samples above a standardised water level index of 160 , thus removing lower elevation samples (see Hamilton and Shennan, 2005 for discussion), and has low RMSEP, although it also has low $r^{2}{ }_{\text {jack }}$ because of the lower number of samples and the reduced length of the elevational gradient (Table 2). The precision of the transfer function is comparable with other foraminifera-based transfer functions from the northern Atlantic Ocean, with a precision ranging from $\pm 0.12 \mathrm{~m}$ to $\pm 0.29 \mathrm{~m}$ (see Leorri et al., 2008a). Following back-transformation of the SWLI values, the reconstructions have a precision of $\pm 0.14 \mathrm{~m}$.

We also employed the modern analogue technique (MAT; Juggins, 2004) to evaluate the likely 
TABLE 2. - Statistics summary of the performance of WA-PLS (weighted averaging partial least squares) for the foraminiferal assemblages from the Basque marshes corresponding to Model 3 (from Leorri et al., 2008a).

\begin{tabular}{|c|c|c|c|c|c|}
\hline Model 3 & Component 1 & Component 2 & Component 3 & Component 4 & Component 5 \\
\hline RMSE & 7.6319 & 6.5124 & 5.7666 & 4.8076 & 4.6526 \\
\hline$r^{2}$ & 0.7343 & 0.80657 & 0.8483 & 0.8945 & 0.9012 \\
\hline Max_Bias & 11.146 & 11.321 & 7.8331 & 6.4407 & 5.5599 \\
\hline & 0.6852 & 0.7176 & 0.7496 & 0.7037 & 0.6504 \\
\hline Mack_Bias & 12.439 & 13.283 & 10.441 & 9.9049 & 16.192 \\
\hline $\mathrm{RMSEP}_{\text {jack }}$ & 8.3254 & 7.8757 & 7.4977 & 8.4911 & 9.5444 \\
\hline
\end{tabular}

reliability of palaeomarsh surface elevation reconstructions based on the transfer function. This technique compares numerically, using the chi-square distance dissimilarity coefficient, the foraminiferal assemblage in a buried sample with the foraminiferal assemblages in all available modern samples. Using the largest minimum dissimilarity coefficient (Woodroffe, 2006), we calculated whether samples have good analogues in the training set (Horton and Edwards, 2006).

\section{RESULTS}

The Muskiz core was located at $4.52 \mathrm{~m}$ above local ordnance datum in the higher vegetated subenvironment of the Muskiz marsh (Fig. 1). The uppermost
$16 \mathrm{~cm}$ of the core are composed of dark brown laminated mud (silt and clay) with a small sand content (average 11\%; range 8-16\%) and are highly organic (average 3.6\%; range 0.9-10.9\%). Below this depth, the sediment is dominated by sand and bioclasts (average $66 \%$; range $23-75 \%$ ) with a low organic matter content (average $1.1 \%$; range $0.6-1.6 \%$ ).

The micropalaeontological analysis showed forty six species and two distinct foraminiferal assemblage zones (FAZ) in this core. The basal $31 \mathrm{~cm}(47-16 \mathrm{~cm}$ depth interval) are characterised by the dominance of transported, allochthonous foraminifera (average $74 \%$ ). The foraminiferal assemblage is dominated by Cibicides lobatulus, and secondary Quinqueloculina lata, Quinqueloculina seminula and Cribroelphidium williamsoni (Table 1). FAZ1 contains a high number of both tests $\mathrm{g}^{-1}$ (average 277; range

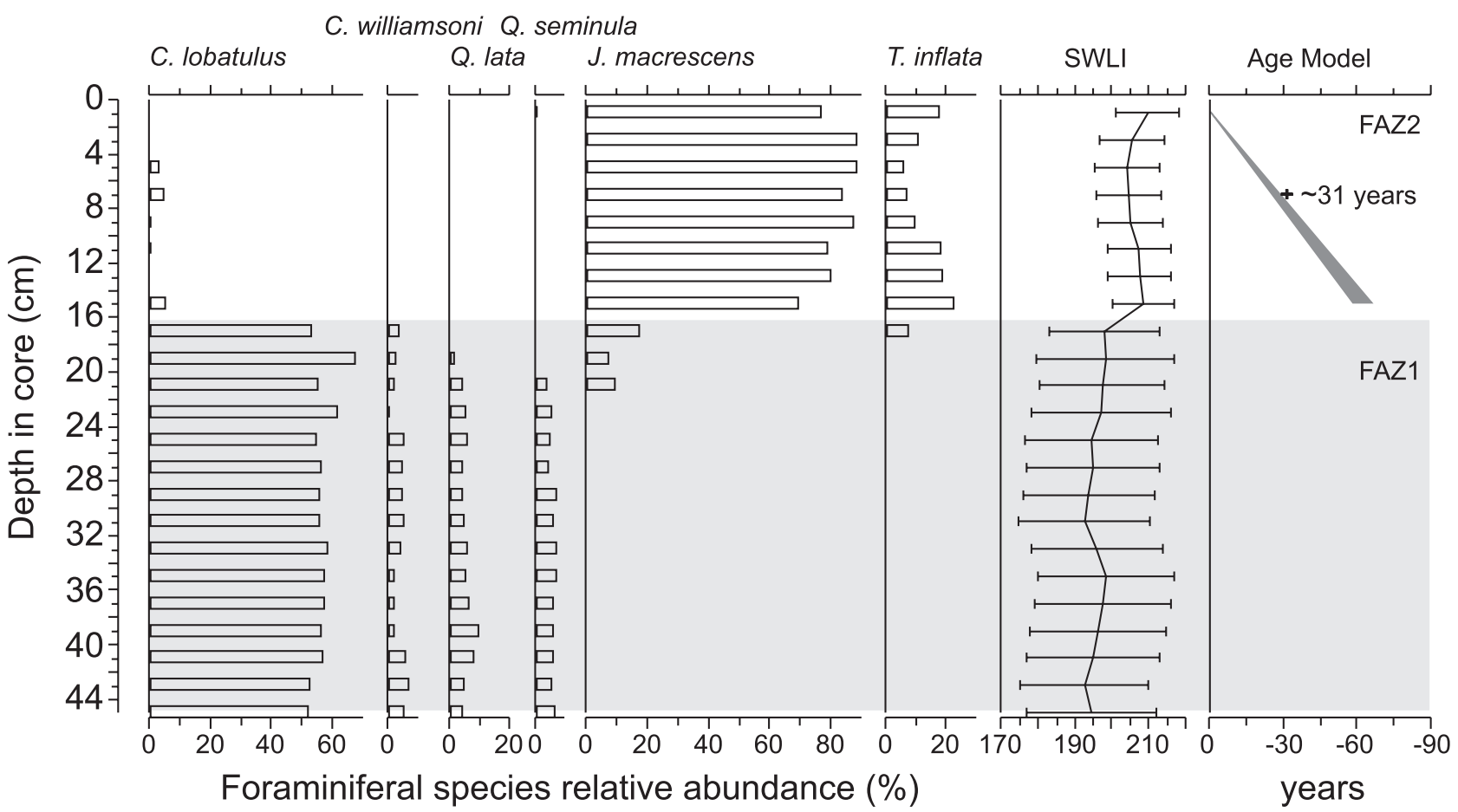

FIG. 2. - Relative abundance of main foraminiferal species, predicted palaeoelevation produced by the transfer function and sedimentation rates-derived age (Table 3 ) with depth $(\mathrm{cm})$ referred to standardised water level index (SWLI). Age model chronology is represented as $2 \sigma$ error (dark grey area). Cross indicates heavy metal concentration-derived age. FAZ, Foraminiferal assemblage zone. 
110-524) and number of species (average 25; range 17-31). The sand content is also high and decreases significantly in the upper $5 \mathrm{~cm}$ of this zone when agglutinated, marsh foraminifera enter the assemblage. By comparison with modern assemblages, FAZ1 has been interpreted as deposited in an intertidal sandy environment with normal marine salinity conditions, which become progressively shallower throughout the last $5 \mathrm{~cm}$ of this zone.

Finally, the top sixteen cm represent current environmental conditions in the vegetated marsh area, with extremely abundant foraminiferal tests (average 1299 tests $\mathrm{g}^{-1}$; range 114-3809) and a very low-diversity foraminiferal assemblage (average 5 species; range 2-7). The organic matter content increases rapidly upwards in this zone from $0.9 \%$ at the base to $10.9 \%$ at the surface. Allochthonous forms are very rare (average 3\%) and only the agglutinated species Jadammina macrescens and Trochammina inflata are dominant. Table 1 and Figure 2 summarise the micropalaeontological data.

Table 3 summarises the radiometric data. ${ }^{210} \mathrm{~Pb}$ activity declines with depth and shows a small er- ror range. The sedimentological change at $-16 \mathrm{~cm}$ prevents the use of the constant rate of supply (CRS) model (Goldberg, 1963), since this environment has probably undergone intense sediment mixing (Leorri et al., 2008b). The data should be normalised to account for the granulometric differences (Cearreta $e t$ $a l ., 2000$ ), making it difficult to obtain a reliable estimation of the supported ${ }^{210} \mathrm{~Pb}$. We therefore used the constant initial concentration (CIC) model, which provides a sedimentation rate of $2.1 \pm 0.1 \mathrm{~mm}^{\text {year }}{ }^{-1}$ for the upper $16 \mathrm{~cm} .{ }^{137} \mathrm{Cs}$ shows a clear subsurface maximum in activity at $-16 \mathrm{~cm}$. Ascribing this subsurface activity maximum to 1963 gives an accretion rate of $4.0 \mathrm{~mm} \mathrm{yr}^{-1}$. However, there is no clear evolution with depth and significant values coexist with others that are well below the detection limit (Table 3).

The aim of this study is not to analyse the geochemical composition of the sediments but to provide additional support for the radiometric age model. We therefore summarise the geochemical results using the $\mathrm{Zn}$ value as representative of the heavy metal variations, following Cearreta et al. (2000), although

TABLE 3. $-{ }^{210} \mathrm{~Pb}_{\text {total }}$, and ${ }^{137} \mathrm{Cs}$ content $\left(\mathrm{Bq} \mathrm{kg}^{-1}\right)$, metal concentrations and metal background values (mg kg-1) in the Muskiz core. Metal background values were calculated for the Basque estuaries by Cearreta et al. (2000). CIC age model with assigned errors and metal concentration-inferred ages are indicated. Age model is calculated from the sedimentation rates obtained from the combination of ${ }^{210} \mathrm{~Pb}$ and metal concentrations for the upper $17 \mathrm{~cm}$.

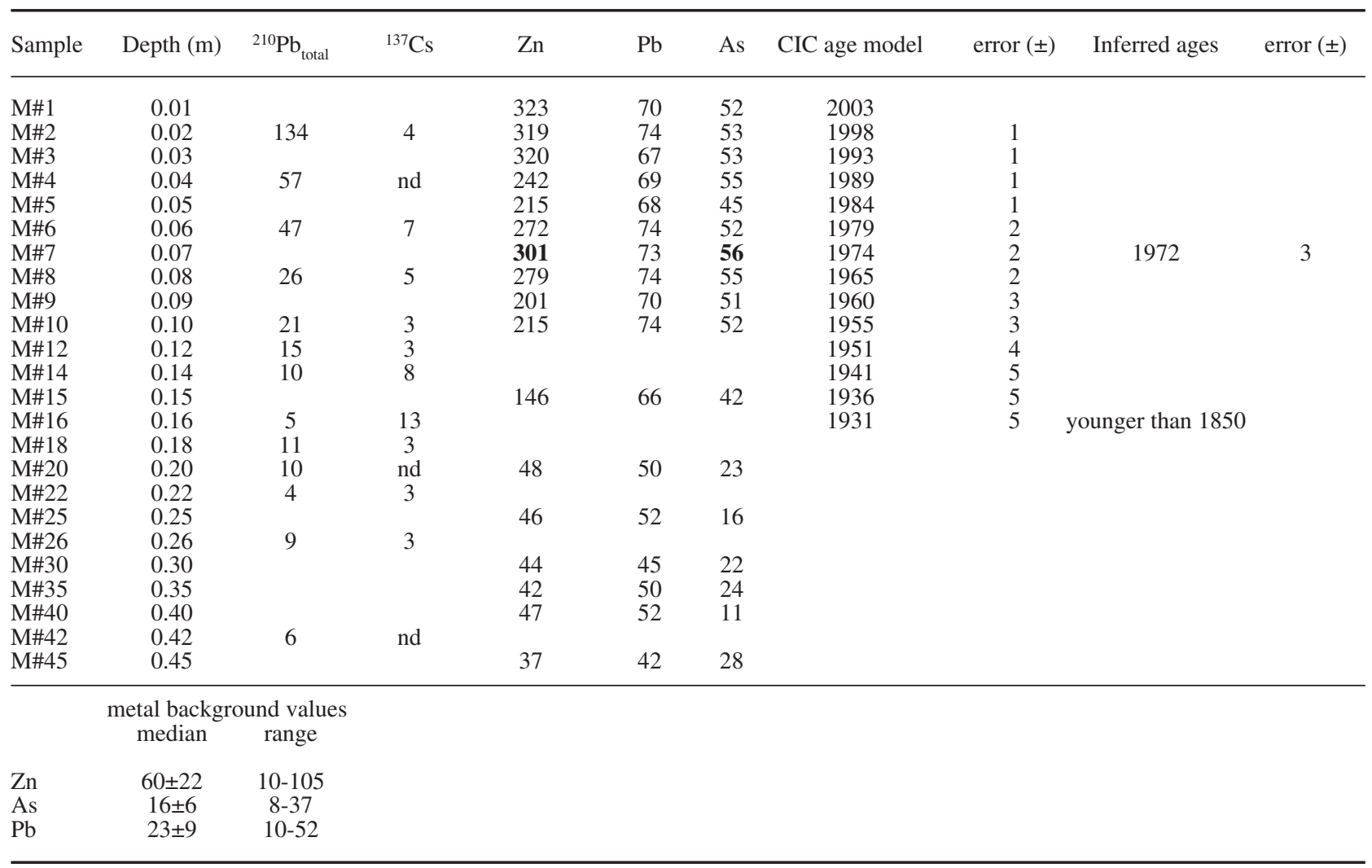


$\mathrm{Pb}$ and $\mathrm{As}$ values are also provided since they have been recently used to support radiometric chronologies. Heavy metal concentrations are fairly constant below $16 \mathrm{~cm}$ and lie within background values (Table 3). From this depth upwards heavy metal values increase, attaining a subsurface sharp peak at -8/-6 $\mathrm{cm}$, before declining towards the surface, although at $-3 /-2 \mathrm{~cm}$ there is an additional increase, peaking again at the surface.

Forty-six species were found in the Muskiz core (Table 1), but only J. macrescens and T. inflata were dominant throughout FAZ2 (Fig. 2). These species are indicative of a high salt-marsh environment. We selected Model 3 transfer function, which consists of modern samples from higher elevations (Table 2), to calibrate the foraminiferal assemblages because the micropalaeontological data suggest a salt-marsh environment for the dated section of the Muskiz core. Furthermore, the buried foraminiferal data exhibit optima high in the tidal frame (above MHHW). The calibration process assigns a palaeomarsh-surface elevation to each core sample together with a bootstrapped standard error of prediction, which varies between 15 and $16 \mathrm{~cm}$ (Fig. 2). The foraminiferal assemblages are fairly similar throughout the FAZ2. Consequently, the transfer function predicts that the marsh surface at the sample site has varied little during deposition of FAZ2, which indicates that the marsh surface has built up largely parallel to the sea-level rise. Slight variations in the palaeomarsh elevation reflect the presence of varying abundances in secondary species. FAZ1 is dominated by calcareous foraminifera, whose modern analogues are not included in Model 3 transfer function. In contrast, MAT indicates that all FAZ2 samples possess good modern analogues in the training set.

\section{DISCUSSION}

Higher high-marsh elevations provide the most reliable sea-level reconstructions since they have a lower influx of inorganic sedimentation due to reduced frequency, duration, and depth of tidal inundation and their dense root mats prevent sediment mixing. Lower elevations are most affected by sediment mixing and pulsating events (e.g. storms), reducing their temporal acuity and providing less accurate sea-level reconstructions when compared with tide-gauge data (Gehrels, 2000; Leorri et al., 2008b). Therefore, only FAZ2 in the Muskiz core can be reliably dated and used to produce a relative sea-level curve.

Recent sedimentation trends (ca. 1850 AD to present) typically employ short-lived radionuclides $\left({ }^{210} \mathrm{~Pb},{ }^{137} \mathrm{Cs}\right) .{ }^{210} \mathrm{~Pb}$ is a naturally occurring radionuclide whose vertical distribution allows ages to be ascribed to sedimentary layers based on the known decay rate of ${ }^{210} \mathrm{~Pb}$ (see Appleby and Oldfield (1992) for a discussion of the ${ }^{210} \mathrm{~Pb}$ method). This technique is restricted to the last 120 years (Gottgens et al., 1999) and needs to be supported by other chronological markers (Smith, 2001). ${ }^{137} \mathrm{Cs}$ (half-life 30 years) is an artificially produced radionuclide present in the environment since 1954. Its presence in the study area is likely to be dominantly derived from nuclear weapons testing, with peak fallout in 1963. However, the use of ${ }^{137} \mathrm{Cs}$ fallout peaks is increasingly viewed as uncertain due to post-depositional migration (Abril, 2004). This effect could be responsible for the discrepancy with the CIC model and the lack of a clear pattern with depth, which prevents the use of ${ }^{137} \mathrm{Cs}$ in this core. To further support the CIC model chronology, we also analysed heavy metal concentrations that have recently been used as chronological markers in high resolution sea-level studies (e.g. Donnelly et al., 2004; Gehrels et al., 2006; Leorri et al., 2008a). In core sediments with continuous records, heavy metal concentration increases gradually from background values, reflecting the increase in emissions as a result of the Industrial Revolution ( 1800 AD). The initial divergence of metal concentrations from background values has been dated in core sediments between 1800 and 1850 (see Leorri et al., 2008a for references). Therefore, FAZ2 should be younger than 1850 since all metals show values above those determined as background in the area by Cearreta et al. (2000). On the other hand, maximum metal concentration has been dated between 1969 and 1975 by numerous authors (e.g. Weiss et al., 1999; Bindler et al., 2001; Eades et al., 2002; Renberg et al., 2002; Farmer et al., 2006), being most likely related to the peak in pollution reached in the early 1970s (Renberg et al., 2002). Ascribing this date to the peak identified at $-7 \mathrm{~cm}$ represented by the $\mathrm{Zn}$ and As profiles, we obtain a sedimentation rate of $2.3 \mathrm{~mm} \mathrm{yr}^{-1}$, which is in excellent agreement with the CIC model-derived sedimentation rates (see Table 3 for summary of data and chronologies).

Figure 3 represents the sea-level reconstruction since the 1920s. Each foraminiferal sampling point is plotted as a sea-level index point using: 

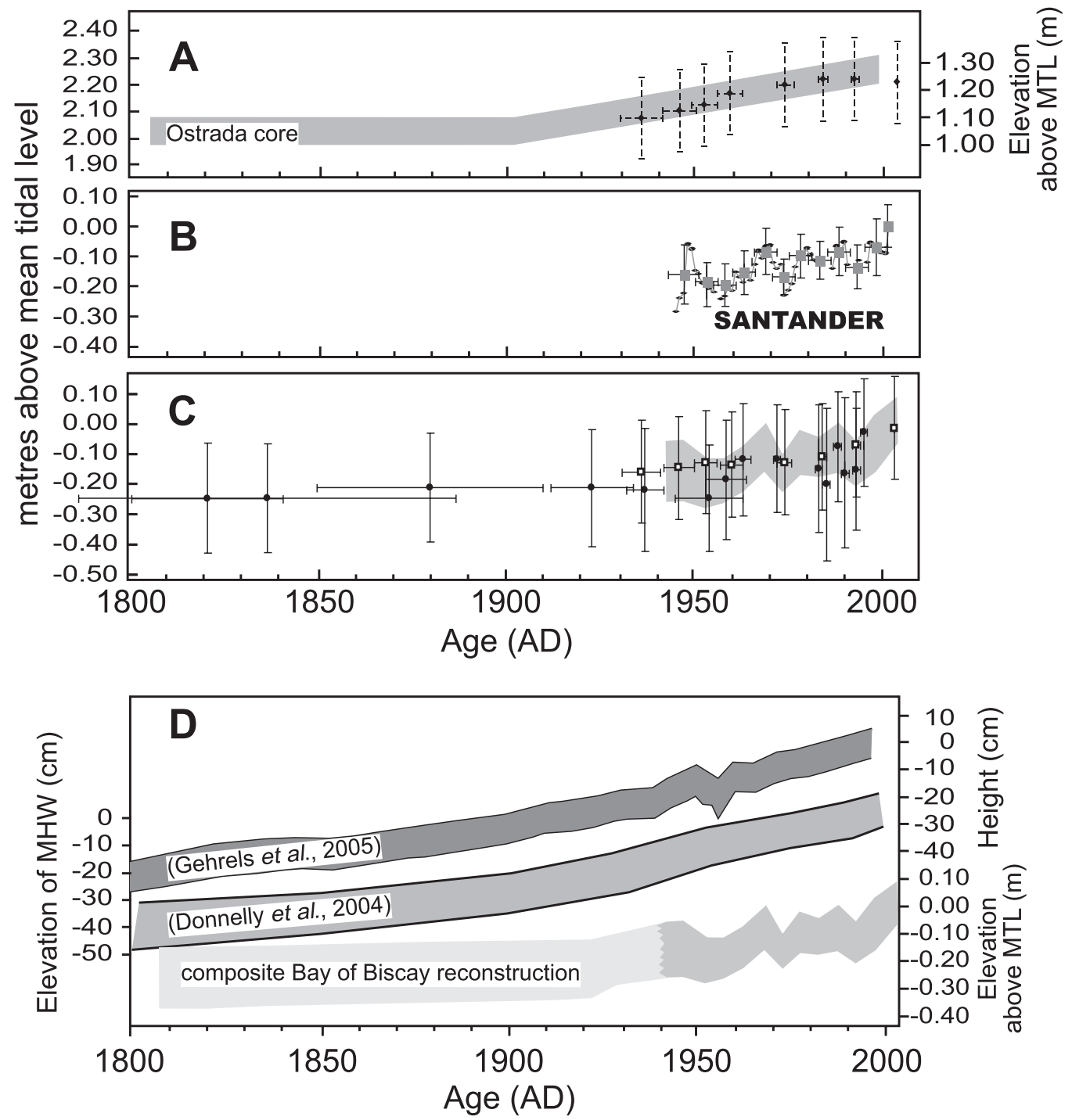

FIG. 3. - Relative sea-level curve for the Muskiz core (Barbadun estuary) derived from both the reconstruction of the elevations produced by the transfer function and the age model chronology. Key: A-Muskiz sea-level reconstruction with assigned errors and the Ostrada (Plentzia estuary) sea-level trend (derived from regression analysis, $95 \%$ confidence; Leorri et al., 2008a). B- Annual and five-year sea-level obtained from the Santander tide gauge (data obtained from the Permanent Service for Mean Sea Level website). C- Comparison between the sea-level index points (derived from both Ostrada cores [circles] and Muskiz cores [squares]) and the Santander tide gauge (envelope based on the five-year reconstruction). D-Comparison between the composite reconstruction of sea-level (sea-level index points and instrumental data) and sea-level general trends from northeastern North Atlantic: dark grey-Gehrels et al. (2005), light grey-Donnelly et al. (2004).

$$
R S L_{i}=E_{i}-P M E_{i}
$$

where $R S L$ is the former relative sea level for sample $i, E$ is sample elevation in metres above the local datum for sample $i$, and $P M E$ is the palaeomarsh elevation in metres above the local datum for sample $i$ reconstructed by the transfer function.

Figure 3 shows an excellent agreement between the Muskiz RSL reconstruction and the Ostrada core inferred trend (Plentzia estuary in Leorri et $a l .$, 2008a). In fact, regression analysis through the mid-point of the reconstruction provides a general trend of $2.3 \pm 0.4 \mathrm{~mm} \mathrm{yr}^{-1}$ for the period 1936-2003, which approximates the results obtained from the Ostrada core that varied from $2.4 \pm 0.4 \mathrm{~mm} \mathrm{yr}^{-1}$ to $2.0 \pm 0.3 \mathrm{~mm} \mathrm{yr}^{-1}$ for the period 1884-1994, depending on whether or not the uppermost sample was included in the analysis, since it was considered a significant outlier (Leorri et al., 2008a). To further explore the reliability of the core reconstructions, we compared the results with the Santander tide-gauge data. We selected Santander due to its proximity to the study area and its record length (since 1943). The Santander tide-gauge linear trend is $2.18 \pm 0.41 \mathrm{~mm}$ $\mathrm{yr}^{-1}$ for the period 1944-2001. However, the temporal resolution of the core reconstructions cannot 
be directly compared to instrumental data that provide a five-minute resolution signal. Therefore, we averaged the tide gauge data at five-year segments providing the mean and the standard deviation $(1 \sigma)$ for each segment (Fig. 3B). The resulting envelope is then used to compare with the reconstructed sealevel index points (see Fig. 3C). The conversion of SWLI to elevation data was done following back the calculations of Equation 1 but using MTL and MHHW corresponding to the Santander tide gauge area so that the instrumental data and transfer function reconstructions could be directly compared (Fig. 3C). As observed in Figure 3C, all but one index point fall within the five-year sea-level envelope, indicating that the reconstructions are consistent with the tide gauge record. Furthermore, the excellent agreement between the two core reconstructions and the tide gauge provides a linear trend of RSL rise of $1.9 \pm 0.3 \mathrm{~mm} \mathrm{yr}^{-1}$ since 1923 . Also, it seems to imply a regional significance of the RSL signal, allowing meaningful comparisons with other areas in the North Atlantic region, as proposed by Leorri et al. (2008a). This composite sea-level curve for the southern Bay of Biscay resembles those reported in northeastern North America (Donnelly et al., 2004; Gehrels et al., 2005) (Fig. 3D), indicating that the modern rate of sea-level rise started at the turn of the century and is roughly coincident with the temperature increase during the 20th century (IPCC, 2007). However, it is still unable to correctly identify the precise timing of the recent sea-level acceleration because of the low number of sea-level index points during the 19th century, and further sediment sequences should therefore be investigated.

\section{CONCLUSIONS}

Accelerating rates of GSLR are increasingly viewed as one of the most devastating impacts of future climate change. However, our understanding of multi-decadal climate-ocean relationships is poor. Geologically-based research can potentially provide accurate estimates of sea-level rise at sub-centennial scales that can be used as benchmarks to measure the additional sea-level rise that has occurred during the last century, supplementing the temporally and spatially limited instrumental data base and indicating when the modern rate of sea-level rise started. This paper has assessed the regional significance of saltmarsh sea-level reconstructions in the southern Bay of Biscay by comparing two different sediment cores recovered from two nearby estuaries and combining tide-gauge and foraminifera-based transfer function reconstructions of RSL. In this geographical area salt-marsh foraminifera show a strong vertical zonation and the use of transfer functions has allowed the first regional quantitative estimate of sea-level index points for the Bay of Biscay. We placed the reconstruction of palaeomarsh elevations into a temporal framework to produce former RSLs. The resulting RSL curve is in very good agreement with local and regional tide-gauge records providing a regional sealevel rise of $1.9 \pm 0.3 \mathrm{~mm} \mathrm{yr}^{-1}$ since 1923 .

\section{ACKNOWLEDGEMENTS}

Dr. Leorri was supported by the contract SFRH/ BPD/44750/2008 (Fundação para a Ciência e a Tecnologia; Portugal). We thank Nieves González for digitalising the data set. This work was partially funded by the UNESCO06/08 and GIC07/32-IT-332-07 research contracts. It represents a contribution to IGCP project \#495. Maria Alday carried out micropalaeontological sampling preparation and foraminiferal counting as part of her $\mathrm{PhD}$ dissertation research supported by a doctoral grant from the Basque Government (Spain). Two anonymous referees greatly improved the original manuscript with their comments and suggestions.

\section{REFERENCES}

Abril, J.M. - 2004. Constraints on the use of ${ }^{137} \mathrm{Cs}$ as a time-marker to support CRS and SIT chronologies. Environ. Pollut., 129: 31-37.

Anonymous. - 1986. Guía del medio ambiente natural de los municipios de Muskiz y Abanto y Zierbana. Servicio Central de Publicaciones del Gobierno Vasco, Vitoria.

Anonymous. - 1999. La red de vigilancia y control de la calidad de las aguas litorales del País Vasco. Años 1995-1996. Colección Recursos Hídricos, 28. Servicio Central de Publicaciones del Gobierno Vasco, Vitoria.

Appleby, P.G. and F. Oldfield. - 1992. Applications of ${ }^{210} \mathrm{~Pb}$ to sedimentation studies. In: M. Ivanovich and R.S. Harmon (eds.), Uranium-series disequilibrium. Applications to Earth, Marine and Environmental Sciences, pp. 731-778. Oxford Science, Oxford.

Bindler, R., I. Renberg, N.J. Anderson, P.G. Appleby, O. Emteryd and $\mathrm{J}$. Boyle. -2001 . Pb isotope ratios of lake sediments in West Greenland: inferences on pollution sources. Atmos. Environ., 35: 4675-4685.

Birks, H.J.B. - 1995. Quantitative paleoenvironmental reconstructions. In: D. Maddy and J.S. Brew (eds.), Statistical modelling of Quaternary science data, Technical Guide 5, pp. 161-254. Quaternary Research Association, Cambridge.

Birks, H.J.B., J.M. Line, S. Juggins, A.C. Stevenson and C.J.T. Ter Braak. - 1990. Diatom and $\mathrm{pH}$ reconstruction. Philos. Trans. R. Soc. Lond., 327: 263-278. 
Boomer, I. and B.P. Horton. - 2006. Holocene relative sea-level movements along the North Norfolk Coast, UK. Palaeogeogr. Palaeoclimatol. Palaeoecol., 230: 32-51.

Cabanes, C., A. Cazenave, and C. Le Provost. - 2001. Sea level rise during past 40 years determined from satellite and in situ observations. Science, 294: 840-842.

Cazenave, A. and R.S. Nerem. - 2004. Present-day sea level change: Observations and causes, Rev. Geophys., 42: 1-20.

Cearreta, A., M.J. Irabien, E. Leorri, I. Yusta, I.W. Croudace and A.B. Cundy. - 2000. Recent Anthropogenic Impacts on the Bilbao Estuary, Northern Spain: Geochemical and Microfaunal Evidence, Est. Coast. Shelf Sci., 50: 571-592.

Cearreta, A., M.J. Irabien, I. Ulibarri, I. Yusta, I.W. Croudace and A.B. Cundy. - 2002. Recent salt marsh development and natural regeneration of reclaimed areas in the Plentzia estuary, N. Spain. Est. Coast. Shelf Sci., 54: 863-886.

Church, J.A. and N.J. White. - 2006. A 20th century acceleration in global sea-level rise. Geophys. Res. Lett., 33: L01602.

Donnelly, J.P., P. Cleary, P. Newby and R. Ettinger. - 2004. Coupling Instrumental and Geological Records of Sea-Level Change: Evidence from southern New England of an increase in the rate of sea-level rise in the late 19th century. Geophys. Res. Lett., 31: L05203.

Douglas, B.C. -2001 . Sea Level Change in the era of the recording tide gauge. In: B.C. Douglas, M.S. Kearney and S.P. Leatherman (eds.), Sea Level Rise; History and Consequences, pp. 3764. Academic Press, San Diego.

Eades, L.J., J.G. Farmer, A.B. MacKenzie, A. Kirika and A.E. Bailey-Watts. -2002 . Stable lead isotopic characterization of the historical record of environmental lead contamination in dated freshwater lake sediment cores from northern and central Scotland, Sci. Total. Environ., 292: 55-67.

Edwards, R.J., O. van de Plassche, W.R. Gehrels and A.J. Wright. -2004. Assessing sea-level data from Connecticut, USA, using a foraminiferal transfer function for tide level. Mar. Micropaleontol., 51: 239-255.

Farmer, J.G., M.C. Graham, C. Yafa, J.M. Cloy, A.J. Freeman and A.B. MacKenzie. -2006 . Use of $206 \mathrm{~Pb} / 207 \mathrm{~Pb}$ ratios to investigate the surface integrity of peat cores used to study the recent depositional history and geochemical behaviour of inorganic elements in peat bogs. Global. Planet. Change., 53: 240-248.

Gehrels, W.R. - 2000. Using foraminiferal transfer functions to produce high-resolution sea-level records from saltmarsh deposits, Maine, USA. Holocene, 10: 367-376.

Gehrels, W.R. - 2004. Sea-level changes during the last millennium. In: M.L. Schwartz (ed.), Encyclopaedia of Coastal Science, pp. 1026-1030. Kluwer Academic, Dordrecht.

Gehrels W.R., J.R. Kirby, A. Prokoph, R.M. Newnham, E.P. Achterberg, H. Evans, S. Black and D.B. Scott. - 2005. Onset of recent rapid sea-level rise in the western Atlantic Ocean. Quat. Sci. Rev., 24: 2083-2100.

Gehrels, W.R., D.F. Belknap, S. Black and R.M. Newnham. - 2002. Rapid sea-level rise in the Gulf of Maine, USA, since AD1800. Holocene, 12: 383-389.

Gehrels, W.R., W.A. Marshall, M.J. Gehrels, G. Larsen, J.R. Kirby, J. Eiriksson, J. Heinemeier and T. Shimmield. - 2006. Rapid sea-level rise in the North Atlantic Ocean since the first half of the 19th century. Holocene, 16: 948-964.

Gehrels, W.R. G.A. Milne, J.R. Kirby, R.T. Patterson and D.F. Belknap. - 2004, Late Holocene sea-level changes and isostatic crustal movements in Atlantic Canada. Quat. Int., 120: 79-89.

Goldberg, E.D. - 1963. Geochronology with ${ }^{210} \mathrm{~Pb}$. In: IAEA (eds.), Symposium on Radioactive dating. pp. 121-131. IAEA, Vienna.

Gottgens, J.F., B.E. Rood and J.J. Delfino. - 1999. Uncertainty in paleoecological studies of mercury in sediment cores. Water Air
Soil Poll. 110: 313-333.

Hamilton. S. and I. Shennan. - 2005. Late Holocene relative sealevel changes and the earthquake deformation cycle around upper Cook inlet, Alaska. Quat. Sci. Rev., 24: 1479-1498.

Hayward, B.W., U. Cochran, K. Southall, E. Wiggins, H.R. Grenfell, A. Sabaa, P.R. Shane and W.R. Gehrels. - 2004. Micropaleontological evidence for Holocene earthquake history of the eastern Bay of Plenty, New Zealand, and a new index for determining the land elevation record. Quat. Sci. Rev., 23: 1651-1667.

Hesse, P.R. - 1971. A text book of soil chemical analysis. Murray, London.

Holgate, S.J. - 2007. On the decadal rates of sea level change during the twentieth century. Geophys. Res. Lett., 34: L01602.

Horton, B.P. and R.J. Edwards. - 2006. Quantifying Holocene Sea Level Change Using Intertidal Foraminifera: Lessons from the British Isles. J. Foramin. Res., Spec. Publ. 40.

IPCC - 2007. Climate Change 2007: The Physical Science Basis. Contribution of Working Group I to the Fourth Assessment Report of the Intergovernmental Panel on Climate Change [Solomon, S., D. Qin, M. Manning, Z. Chen, M. Marquis, K.B. Averyt, M. Tignor and H.L. Miller (eds.)]. Cambridge University Press, Cambridge, United Kingdom and New York, NY, USA.

Juggins, S. - 2004. C2, Version 1.4: Newcastle University, UK, http://www.campus.ncl.ac.uk/staff/Stephen.Juggins/index. html.

Lederer, C.M., J.M. Hollander and I. Perlman. - 1967. Table of isotopes. Wiley and Sons, New York.

Leorri, E., B.P. Horton and A. Cearreta. - 2008a. Development of a foraminifera-based transfer function in the Basque marshes, $\mathrm{N}$. Spain: implications for sea-level studies in the Bay of Biscay. Mar. Geol., 251: 60-74

Leorri, E., R.E. Martin and B.P. Horton. - 2008b in press. Field experiments on bioturbation in salt marshes (Bombay Hook National Wildlife Refuge, Smyrna, DE, USA): Implications for sea-level studies. J. Quat. Sci., doi: 10.1002/jqs.1183

Leuliette, E., R. Nerem and G. Mitchum. - 2004. Calibration of TOPEX/Poseidon and Jason Altimeter Data to Construct a Continuous Record of Mean Sea Level Change. Mar. Geod., 27: 79-94.

Line, J.M., C.J.T. Ter Braak and H.J.B. Birks. - 1994. WACALIB version 3.3-A computer program to reconstruct environmental variables from fossil assemblages by weighted averaging and to derive sample-specific errors of prediction. J. Paleolimnol., 10: $147-152$.

Nerem, R.S., E. Leuliette and A. Cazenave. - 2006. Present-day sealevel change: A review. C. R. Geosci., 338: 1077-1083.

Renberg, I., M.L. Brannvall, R. Bindler and O. Emteryd. - 2002. Stable lead isotopes and lake sediments - a useful combination for the study of atmospheric lead pollution history. Sci. Total. Environ., 292: 45-54

Smith, J.N. - 2001. Why should we believe $210 \mathrm{~Pb}$ sediment geochronologies? J. Environ. Radioactiv., 55: 121-123.

Weiss, D., W. Shotyk, P.G. Appleby, J.D. Kramers and A.K. Cheburkin. - 1999. Atmospheric Pb since the Industrial Revolution recorded by five Swiss peat profiles: enrichment factors, fluxes, isotopic composition, and sources. Environ. Sci. Technol., 33: 1340-1352.

Woodroffe, S.A. - 2006. Holocene relative sea-level changes in Cleveland Bay, North Queensland, Australia. Unpublished Ph.D. thesis, University of Durham, Durham, UK.

Scient. ed.: A. Palanques.

Received March 6, 2008. Accepted September 26, 2008.

Published online March 4, 2009. 